Article - Food/Feed Science and Technology

\title{
Application of an Enzymatic Extract from Aspergillus niger as Coagulant for Cheddar Cheese Manufacture
}

\section{Julia Lombardi ${ }^{*}$}

https://orcid.org/0000-0002-5414-9316

Felicia Ciocia ${ }^{2}$

https://orcid.org/0000-0003-1734-7361

Thérèse Uniacke-Lowe ${ }^{2}$

https://orcid.org/0000-0003-0396-940X

Valeria Boeris ${ }^{1,3}$

https://orcid.org/0000-0002-2978-6743

Patricia Risso ${ }^{1,4}$

https://orcid.org/0000-0002-2700-287X

Paul L. H. McSweeney ${ }^{2}$

https://orcid.org/0000-0002-5625-5657

1Universidad Nacional de Rosario (UNR), Facultad de Ciencias Bioquímicas y Farmacéuticas, CONICET, Rosario, Santa Fe, Argentina; ${ }^{2}$ University College Cork, School of Food and Nutritional Sciences, Cork, County Cork, Ireland; ${ }^{3}$ Pontificia Universidad Católica Argentina, Facultad de Química e Ingeniería, Rosario, Santa Fe, Argentina; ' Universidad Nacional de Rosario (UNR), Facultad de Ciencias Veterinarias, Casilda, Argentina

Received: 2018.03.09; Accepted: 2019.07.04.

${ }^{*}$ Correspondence: julilombardi_89@hotmail.com; Tel.: +54-9-3471-61589 (J.L.)

\section{HIGHLIGHTS}

- A fungal coagulant was used to manufacture Cheddar cheese

- Higher proteolysis developed during cheese making and during ripening

- Coagulation induced by the fungal coagulant affected the composition of the cheese

- Cheese texture was affected by the coagulant used 
Abstract: The coagulation of milk by a serin protease from Aspergillus niger NRRL3 was studied by rheology. Cheddar-type cheese was manufactured using $3.5 \%(\mathrm{v} / \mathrm{v})$ of fungal enzymatic extract and fermentation-produced chymosin was used as control coagulant. Full composition and ripening of both kinds of Cheddar cheese were studied. Differences in the proteolysis of caseins, not only during cheese manufacture but also during ripening, affected cheese composition, texture and peptide profile. Microbial development during ripening was not affected by the coagulant used.

Keywords: Microbial coagulant; Cheese; Biochemistry during ripening.

\section{INTRODUCTION}

Fermentation-produced chymosin (FPC) comprises $70-80 \%$ of the global market for coagulants [1]. However, because of the relatively low acceptance of products containing genetically engineered ingredients and to find new textures and flavours in cheese, alternative coagulants are continuously sought. The most important substitutes include enzymes of microbial origin and plant proteases. Fungal coagulants are only partially appropriate for cheese-making due to their excessive proteolytic activity and high thermostability. Different approaches including chemical modification and genetic engineering tools improved cheese-making properties of these fungal preparations and nowadays they are commercially available [2]. Despite this, there is an interest in discovering new fungal coagulants with natural cheese-making properties, available from cheap sources [3]. A number of papers studying the suitability of 'unmodified' fungal coagulants in cheese manufacture have been published [4-6].

Cheese is ripened for periods ranging from about two weeks to two or more years depending on variety. During ripening biochemical changes occur, resulting in the development of characteristic flavour and texture. Enzymes from residual coagulant are very important in the most complex biochemical change during ripening, the proteolysis [7]. Higher proteolytic activity from fungal coagulants, compared to FPC, can lead to a loss of protein, lower yield, and off-flavour generation. Because of this, unmodified fungal coagulants are generally only used to make fresh or young cheese [2].

The filamentous fungus $A$. niger and its enzymatic preparations have been repeatedly reviewed and accepted (FAO/WHO 1972, 1978, 1981, 1987, 1990) as 'generally recognized as safe' (GRAS) [8]. Production of milk clotting enzymes by the genus Aspergillus has been reported [9]. Even, the ability of $A$. niger proteases to make fresh cheese have been tested [10]. The focus of this work was to use a milk clotting enzymatic extract (EE) from $A$. niger NRRL3 to make young Cheddar cheese (4 month ripening). Moreover, proteolysis during ripening was studied and its effect on texture was also investigated. Commercial FPC was used as control coagulant to compare and contrast the results.

\section{MATERIAL AND METHODS}

\section{Enzymatic extract preparation}

Serine protease production by the fungus Aspergillus niger NRRL3 was carried out by fermentation using industrial wastes as substrates [11]. After its recovery, the EE was frozen and freeze-dried. For cheese-making, the desired amount of freeze-dried EE was dissolved in a small volume of pasteurized cheesemilk from each vat and after homogenization added to the vat.

\section{Determination of the appropriated amount of coagulant addition}

Dynamic oscillatory analysis (small amplitude oscillatory measurement) was carried out using an AR-G2 rheometer (TA Instruments, Waters LLC, UK). Aluminum parallel plate, 60 mm diameter geometry, was used. The oscillation frequency was $1 \mathrm{~Hz}$ and the strain $0.1 \%$, small enough to ensure an undisturbed gel network. EE solution $(68 \mathrm{mg} / \mathrm{mL})$ was added to 4 
$\mathrm{mL}$ of reconstituted skim milk $\left(0.80 \%\right.$ total fat; $36 \%$ protein), previously heated to $32{ }^{\circ} \mathrm{C}$, at different concentrations from 1 to $10 \%(\mathrm{v} / \mathrm{v})$. Three min elapsed between the mixing of $E E$ in milk and the commencement of oscillation. The storage modulus ( $G$ ') and the loss modulus (G") were measured for $90 \mathrm{~min}\left(\right.$ at $32{ }^{\circ} \mathrm{C}$ ). The rheological properties, loss tangent $(\mathrm{LT}=$ G'/G') and G' at 90 min, were registered for each condition. In the present work, gelation time (GT) was considered as the time needed for $\mathrm{G}^{\prime}$ to exceed $1 \mathrm{~Pa}[12,13]$. Each treatment was analyzed in triplicate.

\section{Cheddar cheese manufacture}

Cheddar-type cheese was manufactured on a $10 \mathrm{~L}$ scale according to a standard protocol [14] in the pilot plant facilities of University College Cork, Ireland. Whole milk (3.85\% fat; $3.35 \%$ protein) was standardized to a casein to fat ratio of 0.7 , pasteurized at $63{ }^{\circ} \mathrm{C}$ for $30 \mathrm{~min}$ and cooled to $30^{\circ} \mathrm{C}$ for cheese-making. Starter culture (R-604Y, Lactococcus lactis subsp. lactis, Chr. Hansen Ltd., Ireland) was added to a level of $0.03 \%$ (w/w) in each vat and manually stirred for $30 \mathrm{~min}$. Commercial FPC (CHY-MAX Plus, $200 \mathrm{IMCU} / \mathrm{mL}$, Chr. Hansen Ltd., Ireland) was added at a final concentration of $0.03 \%(\mathrm{v} / \mathrm{w})$ while $A$. niger EE reached a final concentration of $3.5 \%(\mathrm{v} / \mathrm{v})$ in each vat. Once the curd developed enough firmness, the coagulum was cut and cooked from 31 to $39^{\circ} \mathrm{C}$ in a period of $30 \mathrm{~min}$ and held to that temperature until the $\mathrm{pH}$ dropped to 6.2 , when the whey was drained. The curd was then cut into blocks and inverted every $15 \mathrm{~min}$ until the $\mathrm{pH}$ decreased to 5.4. Curd blocks were milled, salted at a level of $2.5 \%(\mathrm{w} / \mathrm{w}) \mathrm{NaCl}$ (Merck, Germany), and equilibrated for $20 \mathrm{~min}$. The salted curds were transferred to $1 \mathrm{~kg}$ cylindrical molds and pressed during $15 \mathrm{~h}$. Each cheese was vacuum sealed and ripened for 4 months at a temperature of $8{ }^{\circ} \mathrm{C}$. Both treatments (type of coagulant: FPC and EE from $A$. niger) were assayed in three independent trials by manufacturing three wheels of each type of cheese.

\section{Compositional analysis}

Full cheese composition was determined at 10 days of ripening. Moisture content was determined by the drying-oven method [15], fat by the Gerber method [16], protein (\% $\mathrm{N} \times$ 6.38) by the macro-Kjeldahl method [17] and salt by potentiometric titration of chloride with $\mathrm{AgNO}_{3}$ [18]. Cheese yield (actual yield, Ya) was calculated by ([weight in $\mathrm{kg}$ of the dried curd/ weight in $\mathrm{kg}$ of the milk] ${ }^{*} 100$ ) [19]. The $\mathrm{pH}$ was measured at 10, 30, 60, 90 and 120 days of ripening on a homogenized mixture of $2 \mathrm{~g}$ of cheese and $4 \mathrm{~mL}$ of distilled water. All analyses were performed in triplicate.

\section{Microbiological analysis}

Samples were taken from each cheese trial as described by Fenelon et al. [20]. Starter lactic acid bacteria (SLAB) were enumerated on LM 17 agar (Merck, Germany) using aerobic incubation at $30{ }^{\circ} \mathrm{C}$ for 3 days [21]. Non-starter lactic bacteria (NSLAB) were counted on Rogosa agar (Merck, Germany) and incubated anaerobically at $30{ }^{\circ} \mathrm{C}$ for 5 days [22]. Enumeration of LAB and NSLAB were performed in duplicate at 10, 30, 60, 90 and 120 days of ripening.

\section{Proteolysis}

Primary and secondary proteolysis of caseins during cheese ripening were determined by analysis of insoluble and soluble fractions at $\mathrm{pH} 4.6$, respectively. Protein extraction at $\mathrm{pH}$ 4.6 was carried out according to McSweeney and Fox [23]. Insoluble protein fractions were analysed by urea-polyacrylamide gel electrophoresis [24] at 10, 30, 60, 90 and 120 days of ripening. Gels were stained with Coomassie blue G250 [25]. Soluble fractions were analysed by Kjeldahl method to determine the soluble nitrogen (SN) [17] and by the trinitrobenzenesulphonic acid method to measure the level of total free amino acids (FAA) [26]. Both assays were carried out at 60 and 120 days of ripening. Peptide profiles of the soluble fractions were determined by reverse-phase ultra-performance liquid 
chromatography (RP-UPLC) at 10, 30, 60, 90 and 120 days of ripening [27]. The system consisted of a Waters Acquity $\mathrm{H}$-Class using a spectrophotometer as detector (elution was monitored at $214 \mathrm{~nm}$ ). The column used was an Acquity UPLC BEH C18 $1.7 \mu \mathrm{m}, 2.1 \mathrm{~mm}$ diameter and $100 \mathrm{~mm}$ length.

\section{Texture profile analysis}

Texture profile analysis (TPA) was performed using a Texture Analyzer TA-XT2i (Stable Micro Systems, UK) at 30, 60, 90 and 120 days of ripening. Cheese samples were cut into cylinders (20 mm diameter, $20 \mathrm{~mm}$ height), placed in airtight plastic bags and equilibrated at $8^{\circ} \mathrm{C}$. After 2 hours, they were removed from the fridge and immediately compressed to $30 \%$ of the original height in 2 consecutive cycles at a rate of $1 \mathrm{~mm} / \mathrm{s}$. Hardness, springiness, and cohesiveness were estimated [28]. Four cheese cylinders were analysed per treatment.

\section{Colour analysis}

Colour analysis of cheese samples was performed using a Konika-Minolta colorimeter CR-400 (Konika-Minolta Optics Inc., Japan) at 120 days of ripening. The instrument was set on the CIELAB system. Four random measurements were performed directly on a fresh piece of cheese at $20^{\circ} \mathrm{C}$.

\section{Statistical analysis}

Data were reported as mean values \pm standard deviations. Comparison between two treatments was carried out by the Student $t$-test when the data fulfilled normal distribution and equal variance. If these conditions were not satisfied, the effect of the treatment was analyzed by Mann-Whitney rank sum test. To analyze the significance of the factors during ripening time, paired t-test was applied when the data fulfilled normal distribution. In other case, Wilcoxon test was applied. Only for TPA results Two-way ANOVA and Tukey test were carried out to compare de results at a significance level of $(p<0.05)$. The software used for data processing was SigmaPlot 12 (Systat Software Inc., USA).

\section{RESULTS}

\section{Determination of the appropriated amount of coagulant addition}

The essential step in the manufacture of all cheese varieties involves coagulation of the casein component of the milk protein system to form a gel [14]. The vast majority of cheese varieties are produced by limited proteolysis, the use of FPC has grown steadily since it was introduced in 1990 and, today, the FPC is applied in more than half of the world's enzyme-coagulated cheese production [29]. Because of this, it is always used as control in the analysis of new coagulants. In order to determine the appropriate EE concentration to use at the coagulation stage during cheese-making, a rheological analysis was carried out. FPC was used as control coagulant to compare the results (data not shown). To focus on the effect of proteases on coagulation, simple model systems were prepared as samples using reconstituted skim milk instead of raw milk and avoiding the addition of starter cultures.

The rheological properties of milk gels obtained using different EE concentrations as coagulant are shown in Table 1. 
Table 1. Rheological properties of milk gels obtained by milk clotting using the enzymatic extract from A. niger as coagulant.

\begin{tabular}{cccc}
\hline [EE] (\% v/v) & GT $(\boldsymbol{m i n})$ & G' at $^{\prime} \mathbf{9 0} \mathbf{~} \min (\mathbf{P a})$ & $\mathbf{L T}$ at $\mathbf{9 0} \mathbf{~ m i n}$ \\
\hline 3 & $45 \pm 2$ & $17 \pm 3$ & $0.3483 \pm 0.0001$ \\
4 & $32.6 \pm 0.4$ & $38 \pm 1$ & $0.3026 \pm 0.0004$ \\
5 & $29 \pm 3$ & $27 \pm 5$ & $0.343 \pm 0.005$ \\
6 & $23.4 \pm 0.2$ & $34.7 \pm 0.5$ & $0.342 \pm 0.004$ \\
7 & $21 \pm 3$ & $35 \pm 3$ & $0.346 \pm 0.002$ \\
8 & $17.7 \pm 0.2$ & $38 \pm 5$ & $0.348 \pm 0.002$ \\
9 & $15.1 \pm 0.5$ & $40 \pm 1$ & $0.350 \pm 0.002$ \\
10 & $15.03 \pm 0.2$ & $35.8 \pm 0.8$ & $0.358 \pm 0.002$ \\
\hline
\end{tabular}

The results obtained using $1 \%$ and $2 \%(\mathrm{v} / \mathrm{v})$ EE are not shown because GT were too long (more than one and two hours, using $2 \%$ and $1 \% \mathrm{EE}$, respectively). Moreover, the stiffness values reached for the gels ( $G^{\prime}$ at $90 \mathrm{~min}$ ) were too low compared to the values needed for cheese-making at the same conditions [13]. As expected, shorter GT were obtained when higher EE concentrations were used. At all the conditions assayed, LT decreased at the gelation point and attained a value which kept constant until the experiment finished [30].To decide how much EE use during cheese manufacture it was necessary to take into account that the set-to-cut time (SCT) for milk gels formed using FPC (control cheese) was around $45-50 \mathrm{~min}$. At that point, the gel reached a stiffness value (G') of at least $20 \mathrm{~Pa}[1,31]$. Using $3 \%(\mathrm{v} / \mathrm{v}) \mathrm{EE}$, the GT was between 43 and $47 \mathrm{~min}$. However, the G' at 90 min for these gels were lower than $20 \mathrm{~Pa}$. If the SCT is too long, changes in cheese composition develop, than later influence also the texture [32]. For all this, $3.5 \%(\mathrm{v} / \mathrm{v})$ EE was used as coagulant for cheese-making. Using this EE concentration the following rheological properties were obtained: $\mathrm{GT}(\mathrm{min})=43 \pm 2$; ' ${ }^{\prime}(\mathrm{Pa})$ at $90 \mathrm{~min}=20.3 \pm 0.9$ and $\mathrm{LT}=0.344 \pm 0.004$.

It is important to mention that the general pattern of gelation curves, G' vs time, was similar for milk gels induced by FPC and each EE concentration (data not shown), although some differences were obtained. In all cases three stages were observed, as was previously reported $[30,33]$. During the first minutes, G' values did not vary significantly with time. When gelation begins, $G$ ' values increase being the gelation rate different for each kind of coagulant. Although the significant increase in $G^{\prime}$ started later, the $d G^{\prime} / d t$ is higher for $E E$ due to its unspecific casein hydrolysis. After gelation, at the third stage, G' values keep constant at the " $G$ ' at 90 min".

\section{Cheese composition and $\mathrm{pH}$}

Full composition of Cheddar cheese made using FPC and EE from $A$. niger as coagulants, is show in Table 2.

Significantly different values of moisture, fat and protein were obtained depending on the coagulant used. Higher proteolysis during casein aggregation by the EE could lead to a softer curd that retained more whey leading to an increase in moisture. This could be explained considering the effect of the texture of the curd when it is cut, since the softer the curd is at cutting, the higher the level of whey retained [32] and also, the higher proteolysis could be increasing the osmosis, increasing whey retention. Anyway, the moisture content of the cheese made using EE as coagulant still fell within the US Standards for Cheddar cheese [34]. 
Table 2. Composition (at 10 days of ripening) of Cheddar cheese using different coagulants.

\begin{tabular}{cccc}
\hline & FPC Cheese & EE Cheese & $\boldsymbol{p}$ value \\
\hline Moisture (\%) & $37 \pm 1$ & $40.0 \pm 0.6$ & $\mathrm{p}<0.001$ \\
Fat (\%) & $31 \pm 2$ & $27 \pm 2$ & $\mathrm{p}=0.004$ \\
Protein (\%) & $25.1 \pm 0.7$ & $24.0 \pm 0.3$ & $\mathrm{p}<0.001$ \\
Salt (\%) & $1.6 \pm 0.1$ & $1.7 \pm 0.1$ & $\mathrm{p}=0.054$ \\
Protein in whey \% & $1.01 \pm 0.01$ & $1.29 \pm 0.03$ & $\mathrm{p}<0.001$ \\
Yield (Kg cheese/100 Kg milk) & $11.2 \pm 0.3$ & $11.3 \pm 0.8$ & $\mathrm{p}=0.742$ \\
\hline
\end{tabular}

The lower fat content in cheese made using the EE could be explained not only due to the higher moisture, but also to the possible presence of lipases in the extract [35-37]. At the same time, the higher proteolysis could explain the lower protein concentration in EE cheese. Accordingly, higher protein concentration was measured in the whey from EE cheese than from FPC cheese.

$\mathrm{pH}$ variation during cheese ripening is shown in Figure 1.

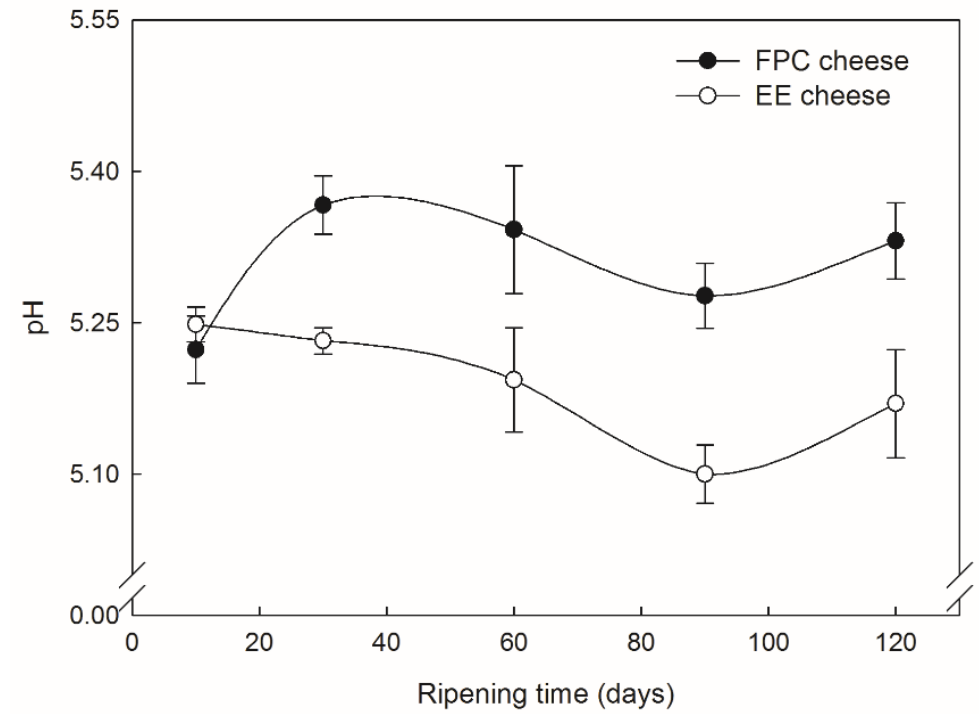

Figure 1. Changes in $\mathrm{pH}$ during ripening of Cheddar cheese made using fermentation-produced chymosin (FPC, filled circles) or enzymatic extract from A. niger (EE, open circles) as coagulants.

In FPC cheese, $\mathrm{pH}$ increased during the first month of ripening and then remained constant during the following 90 days of ripening, usual for Cheddar cheese variety, according to the bibliography [13]. The $\mathrm{pH}$ in EE Cheddar cheese was lower than in FPC cheese and remained also constant during ripening. Proteolytic action of coagulants (hydrolysis) releases protons to the medium decreasing its $\mathrm{pH}$. Higher proteolysis induced by retained $\mathrm{EE}$ in the curd would be responsible for the lower $\mathrm{pH}$ in EE cheese during ripening compared to FPC cheese.

\section{Analysis of ripening}

Starter and non-starter lactic acid bacteria

The results of SLAB and NSLAB enumeration in Cheddar cheese made with either coagulant are shown in Figure $2(\mathbf{a})$ and (b), respectively. 


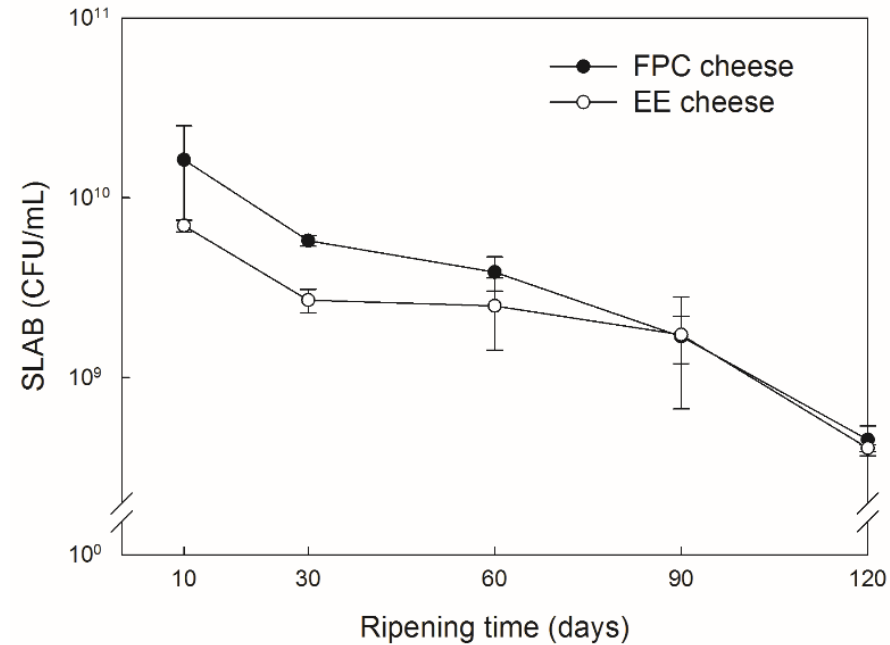

(a)

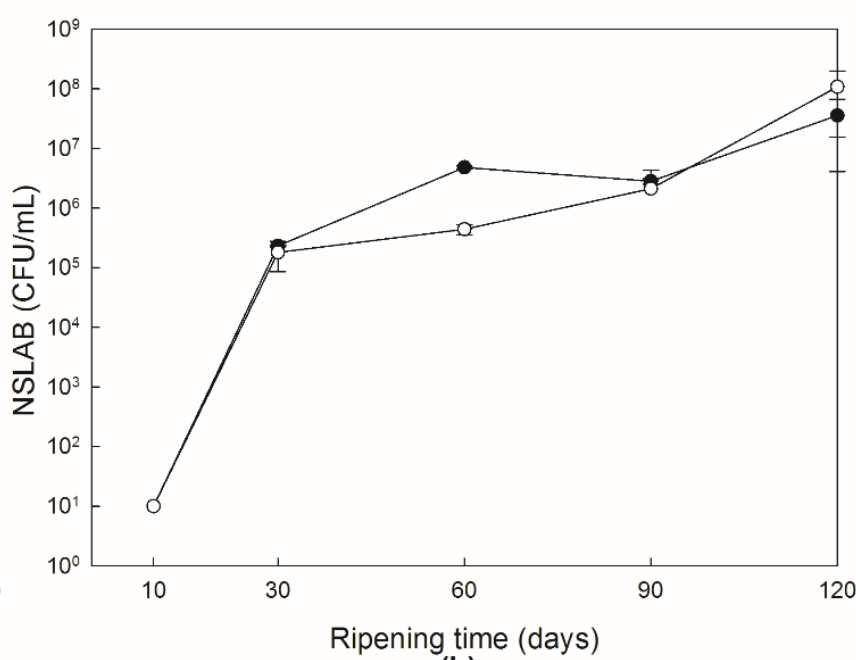

(b)

Figure 2. Numbers of (a) starter lactic acid bacteria (LAB) and (b) non-starter lactic acid bacteria (NSLAB) during ripening of Cheddar cheese made using fermentation-produced chymosin (filled circles) or enzymatic extract from $A$. niger (open circles) as coagulants.

The number of SLAB decreased during the ripening period of 120 days. As expected, no statistically significant differences $(p=0.175)$ were found between treatments. In fresh curd there is a mixture of intact an autolysed SLAB cells, the ratio depending on the type of starter strain used, the manufacturing conditions and the milk composition. During ripening, there is an increase in the number of autolysed cells. A variety of reactions catalysed by both intact and autolysed starter cells influence cheese ripening events and the balance between the two will contribute to the quality of the cheese [38]. Autolysed cells also serve as nutrients for NSLAB, which increased in number during ripening without significant differences between treatments $(p=0.875)$.

\section{Proteolysis}

\section{Primary proteolysis}

Urea-PAGE of the insoluble proteins at $\mathrm{pH} 4.6$ in cheese during ripening is shown in Figure 3. 


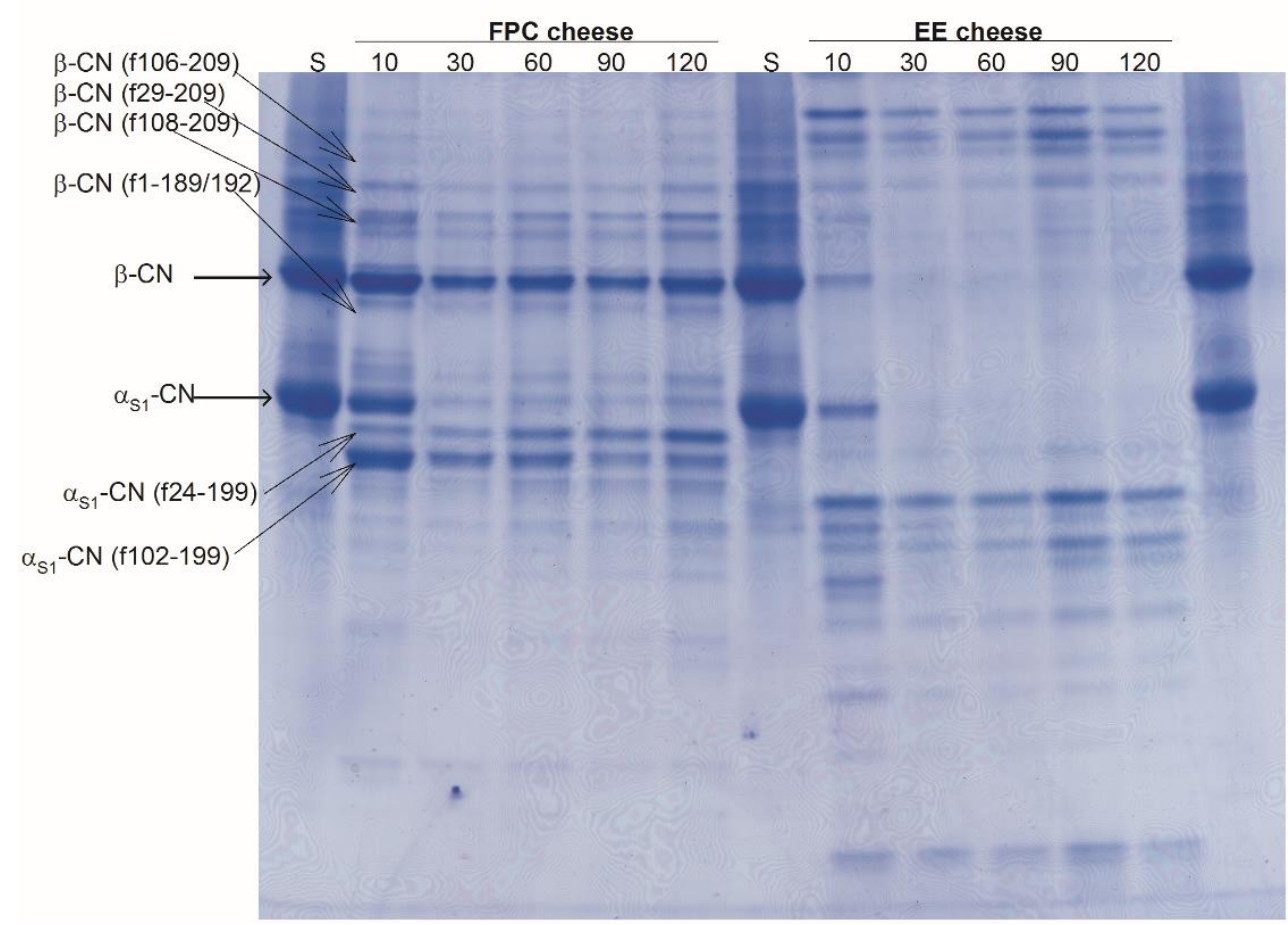

Figure 3. Urea-polyacrylamide gel electrophoretograms of insoluble proteins at $\mathrm{pH} 4.6$ from Cheddar cheese made using fermentation-produced chymosin (FPC) or enzymatic extract (EE) from A. niger as coagulants at 10,30,60,90 and 120 days of ripening. Sodium caseinate was used as standard (S).

In bovine milk $80 \%$ of the proteins are caseins, their isoelectric $\mathrm{pH}$ is 4.6 and the main types are: $\alpha \mathrm{S} 1$-casein $(\alpha \mathrm{S} 1-\mathrm{CN})$, $\alpha \mathrm{S} 2$-casein $(\alpha \mathrm{S} 2-\mathrm{CN}), \beta$-casein $(\beta-\mathrm{CN})$ and $\mathrm{k}$-casein $(\mathrm{k}-\mathrm{CN})$ [39]. However, in Figure 3 the insoluble proteins at $\mathrm{pH} 4.6$ that can be distinguished are $\alpha \mathrm{S} 1-\mathrm{CN}$ and $\beta-\mathrm{CN}$. Both caseins were proteolyzed during ripening, as can be seen by the reduction in intensity of their bands. The most important substrate of plasmin in cheese is $\beta-C N$, which is hydrolysed by this enzyme at three sites: Lys28-Lys29, Lys105-His 106 and Lys107-Glu108, giving rise to the protein fragments $\gamma 1-C N(\beta-C N$ f29-209), $\gamma 2-C N(\beta-C N$ f106-209) and $\gamma 3-C N$ ( $\beta-C N$ f108-209), which separated by PAGE [40]. Coagulant that remains trapped in the curd after whey drainage is also an important source of proteolysis during ripening. Chymosin cleaves $\beta$-casein resulting in the production of short hydrophobic peptides, which are bitter, for example the fragments f1-189/192. The susceptibility of aS1-CN to hydrolysis by chymosin is higher than to plasmin. The primary site of chymosin action on aS1-CN is Phe23-Phe24, which results in the production of a small peptide (f1-23) that is hydrolyzed by starter proteinases. Chymosin cleaves aS1-CN at a number of other sites, particularly Leu101-Lys 102, giving place to the peptide f102-199, which is present in the insoluble fractions of FPC cheese (Figure 3) [7].

As expected, insoluble proteins at $\mathrm{pH} 4.6$ in EE cheese presented a different proteolysis profile than FPC cheese. During cheese manufacture, proteases from the EE digested $\alpha \mathrm{S} 1-\mathrm{CN}$ and $\beta-\mathrm{CN}$ to a greater extent compared to chymosin. Moreover, during ripening, these caseins were completely digested in the EE cheese.

\section{Secondary proteolysis}

Secondary proteolysis leads to the production of amino acids and short peptides (soluble at $\mathrm{pH} 4.6$ ) obtained after primary proteolysis of caseins. Total FAA level and the ratio between the soluble $\mathrm{N}$ at $\mathrm{pH} 4.6$ respect to the total $\mathrm{N}(\mathrm{pH} 4.6-\mathrm{SN} / \mathrm{TN})$ at 60 and 120 days of ripening are shown in Table 3. 
Table 3. Changes in $\mathrm{pH} 4.6$ soluble $\mathrm{N}$ as a percentage of total $\mathrm{N}$ and level of free amino acids, expressed as $\mathrm{mg}$ of L-Leu $\mathrm{p}$ nitroanilide per $\mathrm{g}$ of cheese, at 60 and 120 days of ripening in both kind of cheese.

\begin{tabular}{|c|c|c|c|c|c|}
\hline & \multicolumn{4}{|c|}{ Ripening time } & \multirow{3}{*}{$p$ value } \\
\hline & 2 months & 4 months & 2 months & 4 months & \\
\hline & \multicolumn{2}{|c|}{ FPC cheese } & \multicolumn{2}{|c|}{ EE cheese } & \\
\hline mg L-Leu /g cheese & $14.6 \pm 0.9$ & $19 \pm 1$ & $26 \pm 1$ & $33 \pm 1$ & $p<0.001$ \\
\hline pH 4.6-SN/TN (\%) & $17.0 \pm 0.8$ & $21.9 \pm 0.8$ & $30.9 \pm 0.6$ & $35.3 \pm 0.5$ & $p<0.001$ \\
\hline
\end{tabular}

Secondary proteolysis was higher in EE cheese than in FPC cheese. As expected, proteolysis significantly increased during ripening for all cheeses.

The RP-UPLC peptide profiles of the $\mathrm{pH}$ 4.6-soluble fractions of FPC cheese and EE cheese are shown in Figure 4 (a) and (b), respectively.

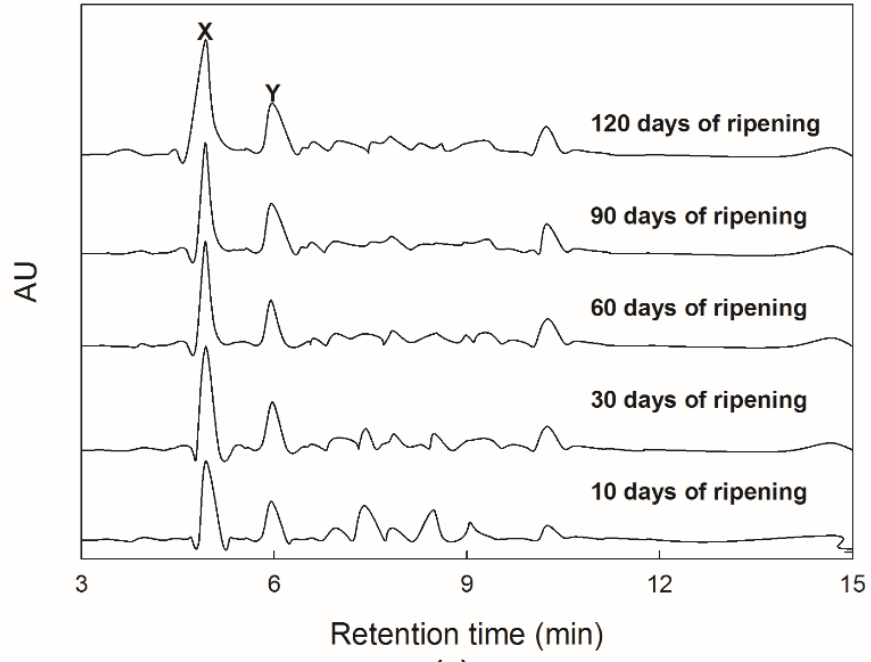

(a)

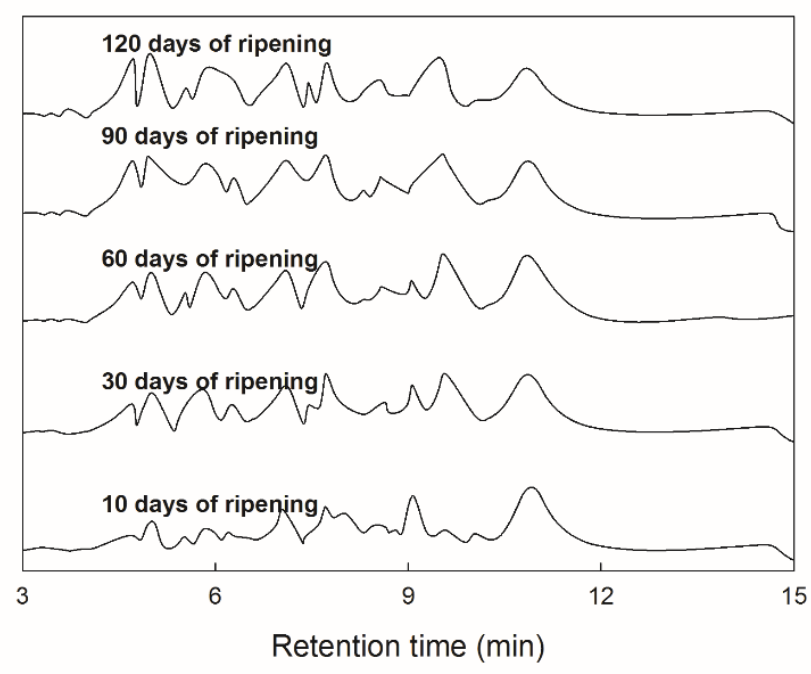

(b)

Figure 4. RP-UPLC peptide profiles of the $\mathrm{pH}$ 4.6-soluble fractions of Cheddar cheese made using (a) fermentation-produced chymosin (FPC) or (b) enzymatic extract (EE) from A. niger as coagulants. Elution was monitored at $214 \mathrm{~nm}$ and a mobile phase of two solvents was used: $A, 0.1 \%(\mathrm{v} / \mathrm{v})$ trifluoroacetic acid in deionised water and B, $0.1 \%(\mathrm{v} / \mathrm{v})$ TFA in acetonitrile.

Only results from trial 1 of each kind of cheese are shown, for trials 2 and 3 similar results were obtained. There were large quantitative differences between the peptide profiles of both kind of cheese as ripening progressed. Two major peptides, produced by the action of Lactococcus proteases on aS1-CN f1-23,can be distinguished in the chromatograms of FPC Cheddar cheese, designed in Figure 4 (a) as $X$ and $Y$ [23]. None of these fragments were present in $\mathrm{pH}$ 4.6-soluble fractions of EE Cheddar cheese. This is because the peptide aS1-CN f1-23 is produced by chymosin but not by EE, as it can be seen in Figure 3 considering the absence of aS1-CN f24-199 in samples from EE cheese. Although the peptide profile of soluble fractions from EE cheese present peaks with similar retention times to $\mathrm{Xe} \mathrm{Y}$, the origin of these fragments is different and their identity remains to be defined. Apart from this, high quantities of other peptides were produced by EE during coagulation and ripening. This is in agreement with the observation that the $\mathrm{pH}$ 4.6-SN/TN in EE cheese was higher than in FPC cheese throughout ripening.

\section{Texture profile analysis}

Results from TPA are shown in Table 4. Significantly lower values of hardness, springiness, and cohesiveness were found for EE cheese than for FPC cheese during ripening. This may be attributed to the higher proteolysis carried out by proteases in the EE 
that soften curd texture during cheese manufacture resulting in a softer cheese with higher moisture content [41].

Table 4. Texture profile analysis parameters hardness, cohesiveness and springiness at $30,60,90$ and 120 days of ripening. Two-way ANOVA and Tukey test were carried out to compare de results at a significance level of $(p<0.05)$.

\begin{tabular}{cccc}
\hline $\begin{array}{c}\text { Ripening time } \\
\text { (days) }\end{array}$ & FPC cheese & EE cheese & p value \\
\hline \multicolumn{4}{c}{ Hardness } \\
\hline 30 & $109 \pm 8$ & $69 \pm 4$ \\
60 & $85 \pm 8$ & $62 \pm 5$ & $<0.001$ \\
90 & $84 \pm 7$ & $71 \pm 6$ & $<0.001$ \\
120 & $82 \pm 8$ & $64 \pm 6$ & $<0.001$ \\
\hline \multicolumn{5}{c}{ Cohesiveness } \\
\hline 30 & $0.27 \pm 0.03$ & $0.152 \pm 0.008$ \\
60 & $0.25 \pm 0.02$ & $0.149 \pm 0.008$ & $<0.001$ \\
90 & $0.20 \pm 0.02$ & $0.12 \pm 0.01$ & $<0.001$ \\
120 & $0.18 \pm 0.02$ & $0.12 \pm 0.01$ & $<0.001$ \\
\hline \multicolumn{5}{c}{ Springiness } \\
\hline 30 & $0.44 \pm 0.04$ & $0.39 \pm 0.02$ & 0.003 \\
60 & $0.44 \pm 0.04$ & $0.23 \pm 0.02$ & $<0.001$ \\
90 & $0.33 \pm 0.03$ & $0.18 \pm 0.02$ & $<0.001$ \\
120 & $0.31 \pm 0.03$ & $0.17 \pm 0.01$ & $<0.001$ \\
\hline
\end{tabular}

Evolution in textural parameters during ripening was not the same in both kinds of cheese: in FPC cheese, a significant decrease in hardness was measured only during the first two months of ripening $(p<0.001)$ but no significant variations were obtained after that time $(p>0.7)$. However, for EE cheese, no significant variations of hardness $(p=0.0691)$ were measured during ripening. This could be explained taking into account the results from UREA-PAGE showed in Figure 3. For EE cheese no variation in the proteolytic profile was detected between 30 and 120 days of ripening. Most proteolysis of caseins induced by EE takes place during coagulation process and before the first month of ripening, as proteolysis is an important factor related to hardness, no significant variation of it was measured after this time.

No significant variations in cohesiveness values of FPC cheese were found between 30 and 60 days of ripening $(p=0.138)$ but after that time a significant decrease was observed ( $p$ $<0.05)$. On the other hand, cohesiveness values of EE cheese significantly decreased after two months of ripening $(p<0.001)$ and remained constant thereafter $(p=0.991)$. Springiness values in FPC cheese significantly decrease after two month of ripening $(p<$ $0.001)$ and remained constant after that ripening time $(p=0.379)$. In EE cheese, springiness significantly decreased during the first three months of ripening $(p<0.05)$ but remained constant during the fourth month $(p=0.885)$. The effect of ripening on the springiness and cohesiveness may be related to the secondary proteolysis. In fact, both the cohesiveness and the springiness are negatively correlated to both soluble $\mathrm{N}$ percentage and the level of free amino acids. The increase in the amount of soluble amino acids or peptides increases the osmotic effect modifying the water behavior in the cheese matrix. 


\section{Colour analysis}

No significant differences $(p=0.085)$ between lightness $\left(L^{*}\right)$ components of FPC cheese $(75 \pm 2)$ and EE cheese $(77 \pm 2)$ were measured at 120 days of ripening. Lower values of yellowness $\left(b^{*}\right)(p<0.001)$ were measured for EE cheese $(28.3 \pm 0.8)$ compared to the ones measured on FPC cheese $(31.1 \pm 0.8)$. Moreover, higher values of greenness $\left(a^{*}\right)$ were measured on EE cheese $(-1.71 \pm 0.09)$ in comparison with FPC cheese $(-3.9 \pm 0.4)$. In spite of these results, these chromatic components are in the range of values reported for Cheddar cheese [13]. This variation measured for the chromatic components could be related to the different levels of fat and moisture in both kind of cheese.

\section{DISCUSSION}

Cheddar cheese was manufactured using an enzymatic extract from $A$. niger as coagulant. Cheddar cheese using fermented-produced chymosin was made as control. Both kinds of cheese were ripened during 120 days, microbiological and biochemical changes developed during this time were studied. The higher proteolysis carried out by the enzymatic extract, not only during casein micelle coagulation but also during ripening, resulted in a softer cheese with a characteristic composition, different colour and peptide profile. According to bibliography [14], the duration of ripening is inversely related to the moisture content of the cheese. Because of this, using EE as coagulant for cheese making would be useful to get softer cheese in a shorter ripening time. This is an advantage from the economical point of view, but also taking into account the increase in cheese varieties. Some milk coagulants alternative to chymosin were tested during the last years and only some of them resulted in good quality cheese products $[4,10,42,43]$. The physicochemical characterization of this new Cheddar cheese opens the possibility of its manufacture in dairy industry. Anyways, further work remains to be done to see the effects of this novel coagulant on cheese flavour as well as on the overall perception of the product.

Funding: Part of this research was funded by the Agencia Nacional de Promoción Científica y Tecnológica (Argentina), grant number PICT-2014-1571. .

Acknowledgments: J. Lombardi gratefully acknowledges the financial support of Consejo Nacional de Investigaciones Científicas y Técnicas (CONICET, Argentina) and AMIDILA-ERAMUS MUNDUS fellowships.

Conflicts of Interest: The authors declare no conflict of interest. The funders had no role in the design of the study; in the collection, analyses, or interpretation of data; in the writing of the manuscript, or in the decision to publish the results.

\section{REFERENCES}

1. Jacob M, Jaros D, Rohm H. Recent advances in milk clotting enzymes. Int J Dairy Technol. 2011;64:14-33.

2. Yegin $S$, Dekker $P$. Progress in the field of aspartic proteinases in cheese manufacturing: structures, functions, catalytic mechanism, inhibition, and engineering. Dairy Sci Technol. 2013;93:565-94.

3. Silveira GG, Oliveira GM, Ribeiro EJ, Monti R, Contiero J. Microbial rennet produced by Mucor miehei in solid-state and submerged fermentation. Brazilian Arch Biol Technol. 2005;48:931-37.

4. Merheb-Dini C, Garcia GAC, Penna ALB, Gomes E, Silva R. Use of a new milk-clotting protease from Thermomucor indicae-seudaticae N31 as coagulant and changes during ripening of Prato cheese. Food Chem. 2012;130:859-65.

5. Alves LS, Merheb-Dini C, Gomes E, Silva R, Gigante ML. Yield, changes in proteolysis, and sensory quality of Prato cheese produced with different coagulants. J Dairy Sci. 2013;96:7490-99.

6. Yasar K, Guzeler N. Effects of coagulant type on the physicochemical and organoleptic properties of Kashar cheese. Int J Dairy Technol. 2011;64:372-9.

7. McSweeney PLH. Biochemistry of cheese ripening. Int J Dairy Technol. 2004;57:127-44.

8. Schuster E, Dunn-Coleman N, Frisvad JC, Van Dijck P. On the safety of Aspergillus niger - a review. Appl Microbiol Biotechnol. 2002;59:426-35. 
9. Vishwanatha KS, Rao AGA, Singh SA. Production and characterization of a milk-clotting enzyme from Aspergillus oryzae MTCC 5341. Appl Microbiol Biotechnol. 2010;85:1849-59.

10. Fazouane-Naimi F, et al. Characterization and cheese-making properties of rennet-like enzyme produced by a local Algerian isolate of Aspergillus niger. Food Biotechnol. 2010;24:258-69.

11. López DN, et al. Peptidase from Aspergillus niger NRRL 3: Optimization of its production by solid-state fermentation, purification and characterization. LWT. 2018;98:485-91.

12. Jaros D, Seitler K, Rohm H. Enzymatic coagulation of milk: animal rennets and microbial coagulants differ in their gelation behaviour as affected by $\mathrm{pH}$ and temperature. Int $\mathrm{J}$ Food Sci Technol. 2008;43:1721-27.

13. Ibáñez RA, Waldron DS, McSweeney PLH. Effect of pectin on the composition, microbiology, texture, and functionality of reduced-fat Cheddar cheese. Dairy Sci Technol. 2015;1-20.

14. Fox P, Guinee T, Cogan T, McSweeney PLH. Fundamentals of cheese science. New York: Springer US; 2000.

15. Cheese and processed cheese products. Determination of the total solids contents. Reference Method 4A. Brussels: Int. Dairy Fed.; 1982.

16. Determination of the percentage fat in cheese. Irish Standard Vol. 69. Dublin: Inst. Ind. Res. Stand.; 1955.

17. Kjeldahl J. A new method for the determination of nitrogen in organic matter. Z Anal Chem. 1883;22:366-82.

18. Fox P. Potentiometric determination of salt in cheese. J Dairy Sci. 1963;46:744-5.

19. Melilli C, Lynch JM, Carpino S, Barbano DM, Licitra G, Cappa A. An empirical method for prediction of cheese yield. J Dairy Sci. 2002;85:2699-704.

20. Fenelon MA, O'Connor P, Guinee TP. The effect of fat content on the microbiology and proteolysis in Cheddar cheese during ripening. J Dairy Sci. 2000;83: 2173-83.

21. Terzaghi BE, Sandine WE. Improved medium for lactic streptococci and their bacteriophages. Appl Microbiol. 1975;29:807-13.

22. Rogosa M, Mitchell JA, Wiseman RF. A selective medium for the isolation and enumeration of oral and fecal lactobacilli. J Bacteriol. 1951;62:132.

23. McSweeney PLH, Fox PF. Chemical methods for the characterization of proteolysis in cheese during ripening. Lait. 1997;77:41-76.

24. Andrews AT. Proteinases in normal bovine milk and their action on caseins. J Dairy Res. 1983;50:45-55.

25. Blakesley RW, Boezi JA. A new staining technique for proteins in polyacrylamide gels using Coomassie Brilliant Blue G250. Anal Biochem. 1977;82:580-2.

26. Fields $R$. The measurement of amino groups in proteins and peptides. Biochem J. 1971;124:581-90.

27. Sousa MJ, Ardö Y, McSweeney PLH. Advances in the study of proteolysis during cheese ripening. Int Dairy J. 2001;11:327-45.

28. Bourne MC. Texture profile analysis [Food acceptability]. Food Technol. 1978.

29. Law BA, Tamime AY. Technology of cheesemaking. 2nd ed. Vol. 18. New York: John Wiley \& Sons; 2011.

30. Lucey JA. Formation and physical properties of milk protein gels. J Dairy Sci. 2002;85:281-94.

31. Costa NE, Hannon JA, Guinee TP, Auty MAE, McSweeney PLH, Beresford TP. Effect of exopolysaccharide produced by isogenic strains of Lactococcus lactis on half-fat Cheddar cheese. $J$ Dairy Sci. 2010;93:3469-86.

32. Johnson ME, Chen CM, Jaeggi JJ. Effect of rennet coagulation time on composition, yield, and quality of reduced-fat Cheddar cheese. J Dairy Sci. 2001;84:1027-33.

33. Lombardi J, Spelzini D, Corrêa APF, Brandelli A, Risso P, Boeris V. Milk protein suspensions enriched with three essential minerals: Physicochemical characterization and aggregation induced by a novel enzymatic pool. Colloids Surfaces B Biointerfaces. 2016;140.

34. Ulpathakumbura CP, Ranadheera CS, Senavirathne ND, Jayawardene LPINP, Prasanna PHP, Vidanarachchi JK. Effect of biopreservatives on microbial, physico-chemical and sensory properties of Cheddar cheese. Food Biosci. 2016;13:21-25. 
35. Kamini NR, Mala JGS, Puvanakrishnan R. Lipase production from Aspergillus niger by solid-state fermentation using gingelly oil cake. Process Biochem. 1998;33:505-11.

36. Mahadik ND, Puntambekar US, Bastawde KB, Khire JM, Gokhale DV. Production of acidic lipase by Aspergillus niger in solid state fermentation. Process Biochem. 2002;38:715-21.

37. Pokorny D, Cimerman A, Steiner W. Aspergillus niger lipases: induction, isolation and characterization of two lipases from a MZKI A116 strain. J Mol Catal B Enzym. 1997;2:215-22.

38. Crow VL, Coolbear T, Gopal PK, Martley FG, McKay LL, Riepe H. The role of autolysis of lactic acid bacteria in the ripening of cheese. Int Dairy J. 1995;5:855-75.

39. Phadungath C. Casein micelle structure: a concise review. Songklanakarin J Sci Technol. 2005;27:201-12.

40. Fox PF. Chees: chemistry, physics, and microbiology. Elsevier; 2004.

41. O'Mahony JA, Lucey JA, McSweeney PLH. Chymosin-mediated proteolysis, calcium solubilization, and texture development during the ripening of Cheddar cheese. J Dairy Sci. 2005;88:3101-14.

42. Shah MA, Mir SA, Paray MA. Plant proteases as milk-clotting enzymes in cheesemaking: a review. Dairy Sci Technol. 2014;94:5-16.

43. Reps A, Jêdrychowski L, Wisniewska K, Jankowska A. Application of a coagulating preparation obtained with Rhizomucor miehei N in cheese-making. Pakistan J Nutr. 2006;5:97-101.

2018 by the authors. Submitted for possible open access publication under the terms and conditions of the Creative Commons Attribution (CC BY NC) license (https://creativecommons.org/licenses/by-nc/4.0/). 